\title{
RELEVANCY OF INDOOR TEMPERATURE AND FENG SHUI LUO PAN COMPASS: THE CASE OF DOMESTIC BUILDINGS IN SURABAYA, INDONESIA
}

\author{
Juan Hogianto ${ }^{1}$, Christina E. Mediastika ${ }^{1^{*}}$ \\ ${ }^{1}$ Department of Architecture, Petra Christian University \\ Jl. Siwalankerto 121-131, Surabaya 60236, Indonesia \\ *Corresponding author; Email: eviutami@petra.ac.id
}

\begin{abstract}
This paper reports an investigation of the scientific justification of room temperature and the beliefs on Luo Pan Compass; a part of Feng Shui wisdom. The compass is a rule of thumb on the placement of a particular room within a house to achieve indoor comfort and occupants' well-being based on house orientation to the wind direction. The study was conducted in a quantitative method that consists of field measurements and questionnaire survey. The result was to be consulted with indoor temperature comfort standard and to the Luo Pan Compass. Eight houses were selected in a purposive method. The investigation showed that the indoor temperature of seven out of eight studied houses were not within the standard. It was in good agreement with the respondents' opinions. Building designers may refer to the finding of this study that Luo Pan Compass is relevant to the temperature comfort level of the indoor environment.
\end{abstract}

Keywords: Indoor temperature; house; Luo Pan compass; feng shui.

\section{INTRODUCTION}

Chinese is well-known as a society with various settled cultures. The Chinese people who migrated to many places around the world brought their culture to where they currently dwell, including those who migrated to Indonesia. The history mentions that Indonesian ancestor came from Yunnan in China. The descendant of migrated Chinese who resides presently in Indonesia remains exercising their tradition in their daily life. One of the myths which still in use is Chinese old-philosophical system of harmonizing human with the surrounding environment; known as Feng Shui. The most visible case to find Feng Shui application in Indonesia is in term of building design and construction. The consideration of Feng Shui in the building seems not only found in Indonesia but remains popular in many other locations in the world (Rossbach, 1983).

In Indonesia, East Java is the fifth Chinese largest population after Jakarta; the capital city; West Borneo, North Sumatra, and West Java (Setiono, 2011). In 2010, the Chinese community in East Java reached 244.393 people, who mostly live in Surabaya. Here, the author decides to study whether or not the Chinese lives in Surabaya exercises Feng Shui in their private buildings, which part of Feng Shui wisdom is applied, and what the consideration behind the Feng Shui application. It includes a study of the relevant relationship between Feng Shui and building science (limited to the indoor temperature that affects thermal comfort).
There are many aspects of Feng Shui wisdom. One of them is Luo Pan Compass; a rule of thumb used to decide housing layout plan based on its orientation to the wind direction (Cheng \& Kong, 1993). Chinese who apply Feng Shui to their house are divided into two groups. First are those who see Feng Shui as a tradition that must be preserved to create harmony (Pheter et al, 2013). Second are those who believe Feng Shui may bring comfort and wellbeing of the occupants based on building science, such as wind flow or sun radiation (Yi, 2007). Nonetheless, even the second group is unable to give a complete and scientific explanation to support their belief that Feng Shui brings a massive contribution to building thermal system (Wicaksono, 2009).

Earlier studies or research about Feng Shui in general and Luo Pan Compass and indoor thermal comfort, in particular, is also minimal. Some that can be used are studies by He (1990), Cheng \& Kong (1993), Mak \& Ng (2005), and Mak \& Ng (2005) about an approach of Feng Shui, known as The Form School approach. It has been well recognized and widely accepted as it comprises a scientific basis for the analysis of the built environment. It may stand as an indication that Feng Shui is a kind of philosophic system that created based on a scientific basis. Nonetheless, further studies to verify it are required. One study is reported in this paper.

In designing private residence, thermal quality has a significant role in indoor human comfort. Comfort level depends on temperature, humidity, insulation, metabolism, radiation temperature, and 
wind velocity (ASHRAE, 2010). Related to the indoor temperature of a building, fluctuation of temperature and humidity inside an area that is influenced by solar radiation, is the most significant factor to be observed. In domestic buildings where the use of air conditioning (AC) is dominant, air circulation between inside and outside hardly exists. The study reported here hold a hypothesis that there is a somewhat relationship between Feng Shui and building thermal comfort.

Based on Wicaksono (2009), etymologically Feng Shui derived from 2 words, Feng (wind) and Shui (water). It means that Feng Shui is a knowledgebased on wind and water elements. Since wind and water are flowing feature, Feng Shui is also a liquid form. In the building context, these elements flow from outside to inside and the vice versa. This flow is called chi, which brings a positive effect on building occupants. In a building, an appropriate opening location will support a good chi.

In Feng Shui, there is also Kua; a short terminology of Pa-Kua; that is utilized to regulate the location and orientation of human activities, such as location and orientation of sleeping, location and orientation of working and many more Dian (1996a) and Dian (1996b). Pa-Kua also functioned as a compass to arrange the interior layout in a building. This compass is named Luo Pan, which classifies area in a building for the good and lousy zone or location due to its orientation to the wind direction (Figure 1). The best position is recommended for the bedroom, living room, family room, kitchen and dining room. Meanwhile, the bad location is used for bathroom, garage, storage and other places that are less likely to accommodate significant activities. For each of 8 wind direction of the compass, Luo Pan has a particular location of the good and bad area.

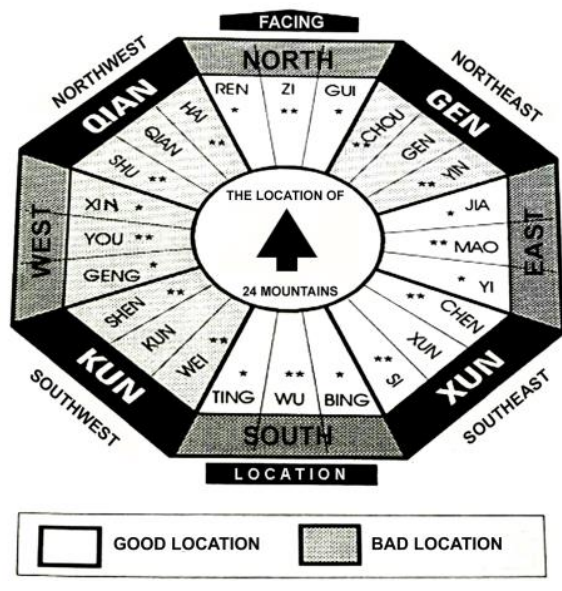

Fig. 1. An example of Luo Pan Compass usage for a Northoriented house to confirm the good or bad zone in it (Dian, 1996b).
By the Feng Shui side, a room in a house can be checked whether in a good or bad location by using a Luo Pan Compass. Meanwhile, by the science-based side, the thermal comfort of a room inside a house somewhat depends on room orientation to solar radiation and wind direction that mainly affects indoor temperature. DeKay \& Brown (2013) mentioned that the level of solar energy radiated through building envelopes is directly related to the area, orientation, and transmission characteristic of the envelopes. It causes each room in a house receives a different level of radiation, which affects the temperature inside the room. Based on Indonesia Standardization (SNI, 1993) which was derived from the Olgyay's bioclimatic chart and the Carrier's psychrometric chart, the standard of comfort temperature in an Indonesia building ranges between 20.8 to $27.1^{\circ} \mathrm{C}$. Temperature between 20.8 to $22.8^{\circ} \mathrm{C}$ is categorized as comfort-cool, between 22.8 to $25.8^{\circ} \mathrm{C}$ is the optimal comfort, and between 25.8 to $27.1^{\circ} \mathrm{C}$ is comfortwarm. The objective of the study is to investigate a room's location according to Luo Pan Compass and the indoor temperature as a consequence of the location. The relevancy between the beliefs and the indoor comfort based on the standard and in-situ measurement is also to be investigated. The study is limited to measuring the indoor temperature only, as it is the main factor affecting indoor comfort in a warm climate. The recorded indoor temperature is already a resultant temperature of solar radiation, airflow, and indoor activities and home appliances (if any).

\section{RESEARCH METHODS}

The study was conducted using a quantitative method with on-site metering and questionnaire survey. The data were collected in Citraland Housing, Surabaya, Indonesia (Figure 2). Citraland is a housing area, mostly for the high-income family. It was selected with a consideration that in a high-class housing, the owners have more opportunity to design or redesign their house and that Feng Shui is more likely to be applied.

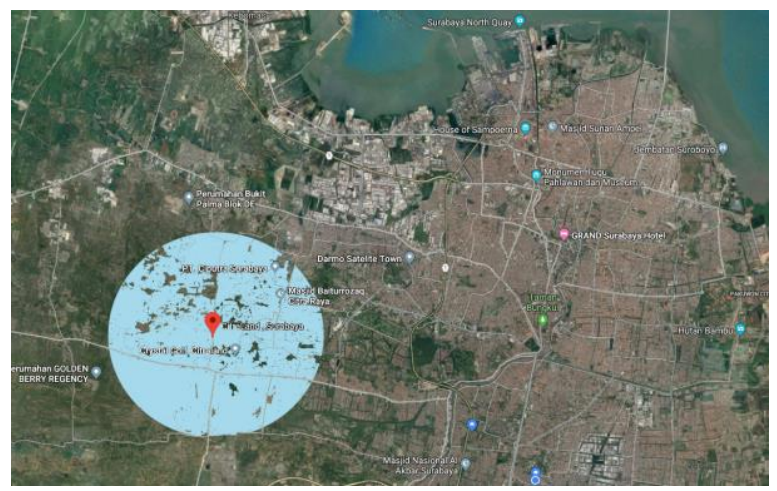

Fig. 2. Citraland housing area in West part of Surabaya; the light blue circled area (after google maps). 

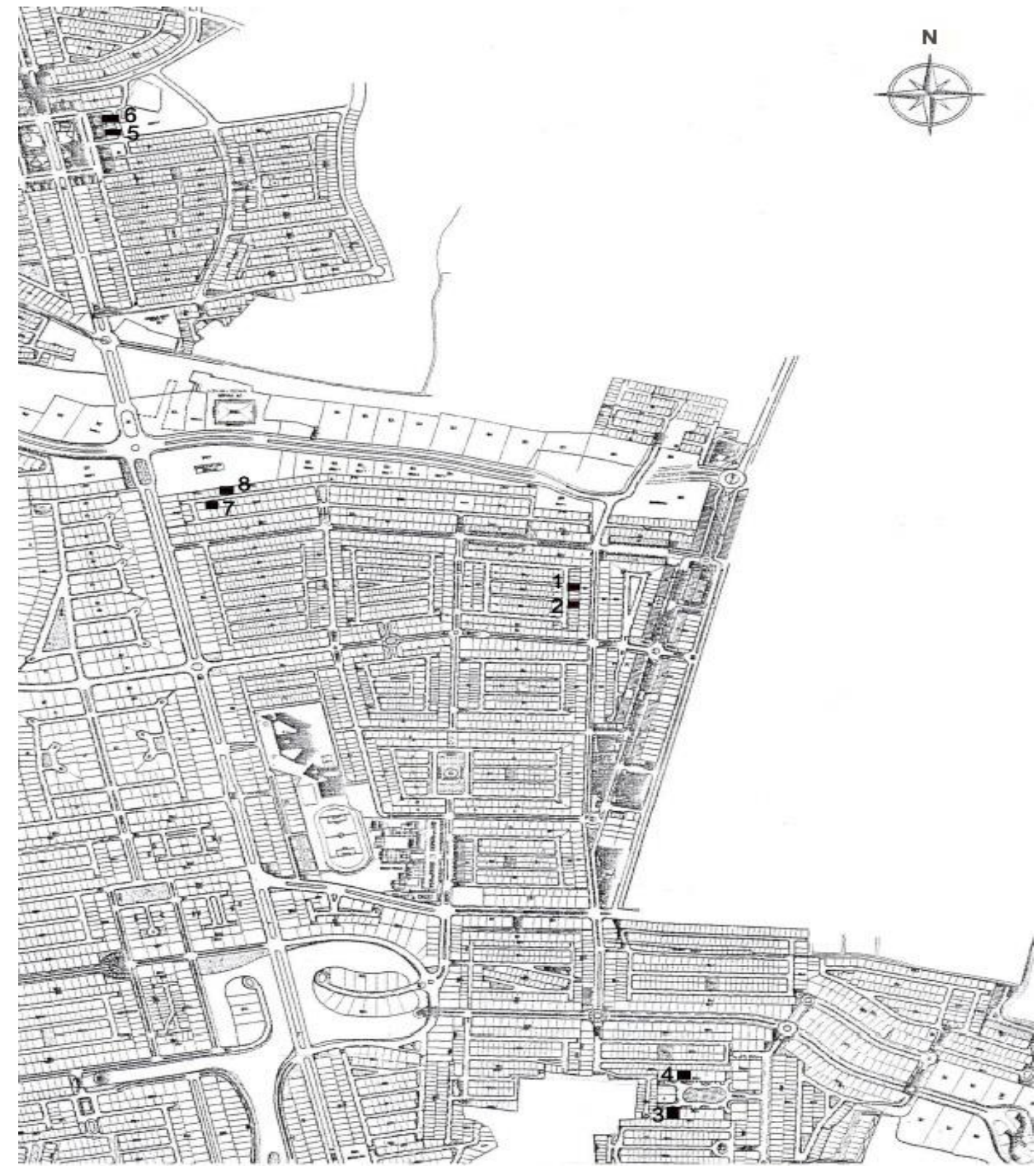

Fig. 3. The location of the 8 observed house in Citraland Housing (black-coloured and numbered).
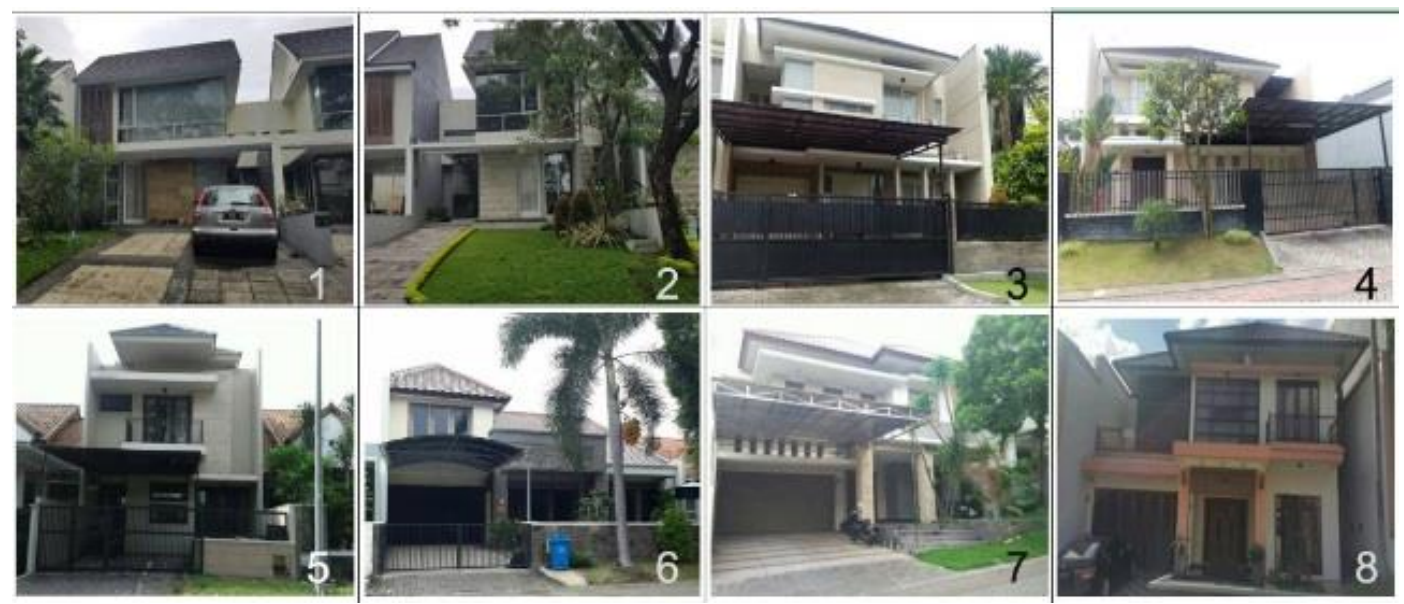

Fig. 4. The elevation of the 8 observed houses. 
At the first stage, the house owners' survey was conducted to plot which houses were owned by the Chinese. It then followed by a survey of the Chinese owners who still use Feng Shui. The last stage was a survey of owners who approved in-situ measurement and agreed to fill out the questionnaire. This study required the installation of measuring tools for 48 hours, which might interfere with the occupants' activities. It turned out 8 houses only gave permission. The detailed location of the 8 houses and their façades are as Figures 3 and 4.

It was a fortunate coincidence that the 8 surveyed houses face different orientation, which allowed the Luo Pan Compass and the relevancy of indoor temperature to be wholly observed. Two essential rooms in each house, i.e., the main bedroom and living room were observed. The layout plan of 8 houses was overlayered with the good and bad location, according to Luo Pan Compass based on their orientation (Figure 5). From here, we found out whether the main bedroom and living room in a good or bad agreement with the compass. If the room is in a good location based on Luo Pan Compass, chi has occurred, and the vice versa. The chi character here was then reduced to be reflected by the indoor temperature recorded in the studied only room. Again, the recorded indoor temperature is a result of solar radiation, airflow, and indoor activities and home appliances (if any). It is then to be consulted with the indoor temperature standard (SNI, 1993).

The indoor temperature was recorded using HOBO Data Logger U12-012 for 48 hours $(2 \times 24$ hours). The measurement was conducted on April 2017, which is a transitional period between the rainy and the dry season in Indonesia. The outdoor temperature range during this period is generally high. During the measurement, the weather in West Surabaya was sunny, with the outdoor temperature range between $24^{\circ} \mathrm{C}$ and $35^{\circ} \mathrm{C}$ and the relative humidity range were between $60 \%$ and $80 \%$ (source: BMKG Surabaya; meteorological and geophysical bodies of Surabaya). The indoor temperature was collected 48 hours only to minimize the inconvenience of the occupants but was considered sufficient to provide an accurate temperature experienced by the occupants. In line with the indoor temperature measurement, a questionnaire survey was conducted. The questionnaire survey was intended to collect occupants' perception of the Feng Shui and the indoor temperature. The result of the in-situ measurement and questionnaire was to be consulted to come to the finding of this study.

\section{FINDINGS and DISCUSSION}

House plan that shows the location of observed rooms was matched to Luo Pan Compass, as is Figure
5. Here we see that all bedrooms are located in the bad zone of Luo Pan Compass, either partially or wholly. The living rooms are mostly situated in between good and bad area. These findings reflect that even during the pre-survey, the house owners stated that they still exercise Feng Shui, they did not apply the Luo Pan Compass in particular. Figure 5 shows that for a building with a limited floor area such as domestic buildings, the application of Luo Pan Compass is hardly applied. Here we see most rooms in the observed houses are in the overlapped area between good and bad. It will not happen in a building with a spacious floor area, where there is no overlapped area.

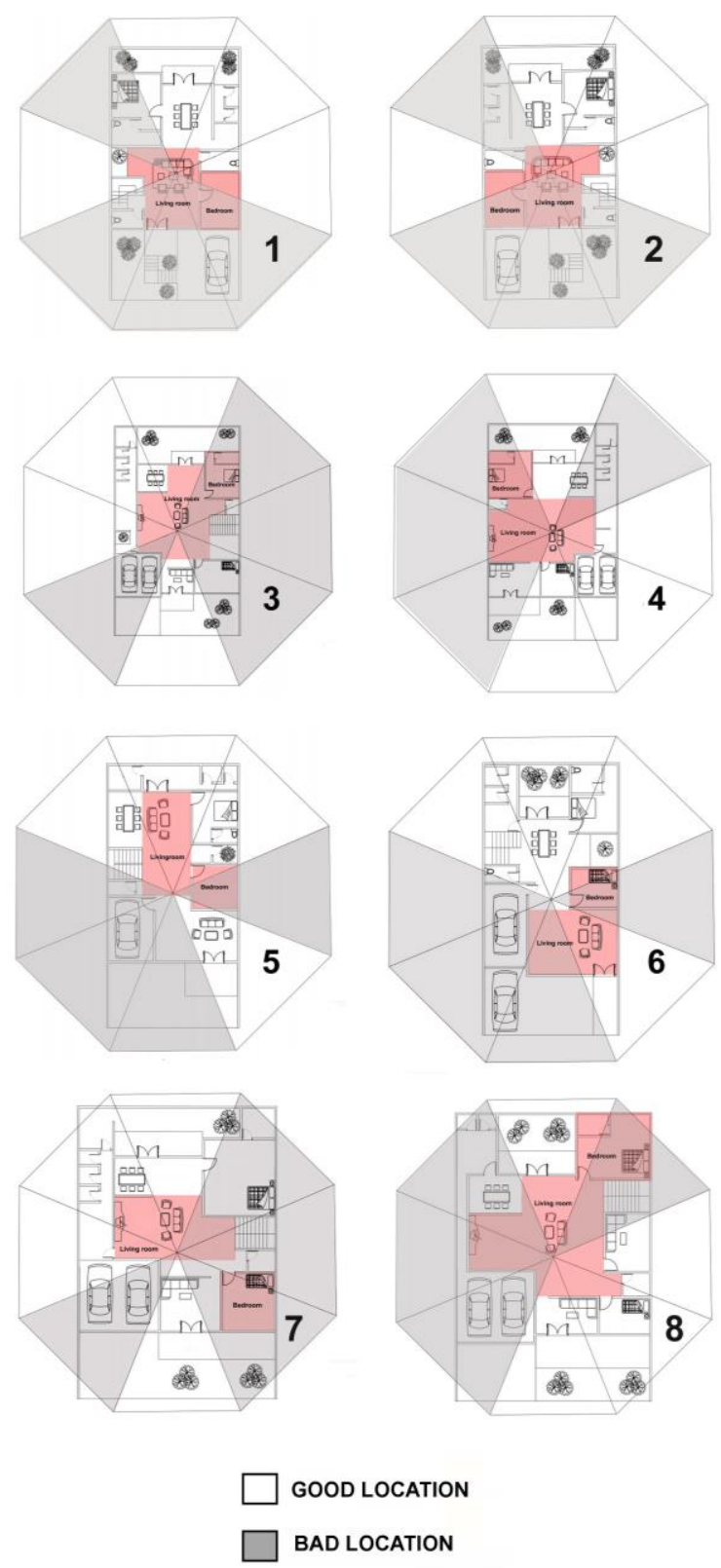

Fig. 5. House plan showing the location of the bedroom and the living room which are over-layered with Luo Pan Compass. 
The indoor temperature recorded by $\mathrm{HOBO}$ is shown in Figures 6 to 13. During the measurement period, the observed rooms were running as their usual daily condition, means where the air conditioner was on, it remained on, and where the window or door was opened or closed, they remained as they were, and where the light was on, it remained on, etc. The moment when AC was turned on is inevitable because the house was occupied during the survey. The real room condition was deliberately set to capture the real chi exists daily in the rooms. Thus the finding of in-situ temperature measurement would likely represent the Feng Shui experienced by the occupants (if any). By this, a linkage found among the room location due to Luo Pan Compass, in-situ measurement, and occupants' perception is more reliable.

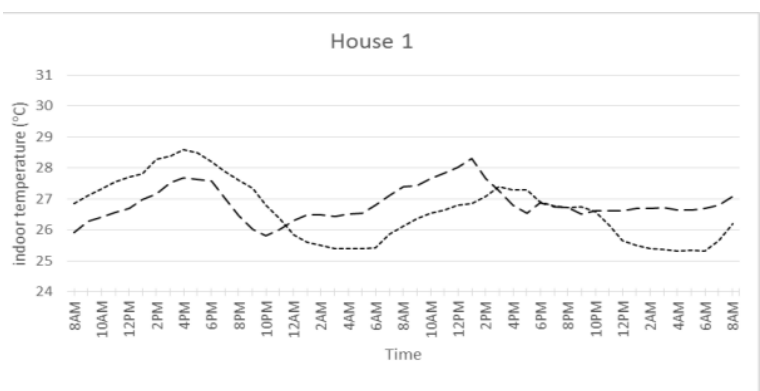

Fig. 6. The recorded indoor temperature of bedroom and living room of house 1 .

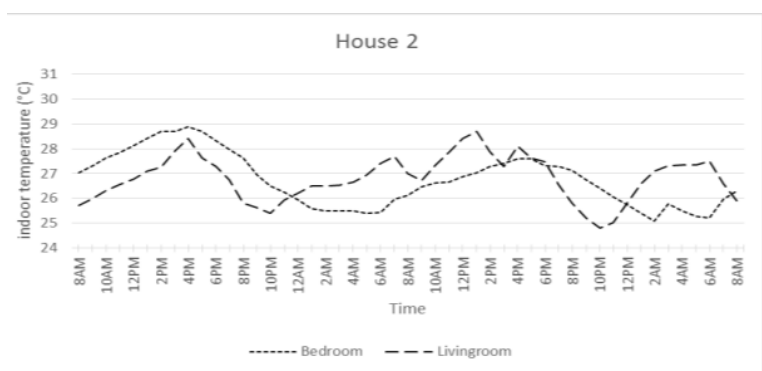

Fig. 7. The recorded indoor temperature of bedroom and living room of house 2 .

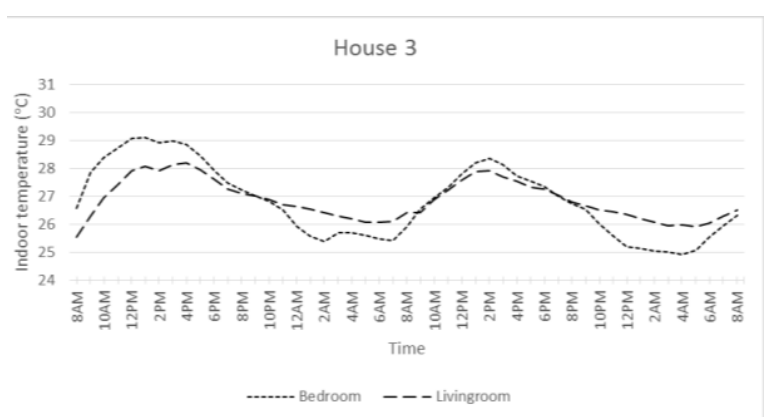

Fig. 8. The recorded indoor temperature of bedroom and living room of house 3 .

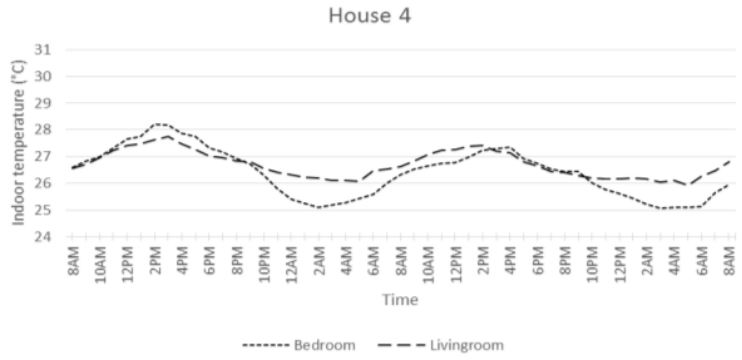

Fig. 9. The recorded indoor temperature of bedroom and living room of house 4 .

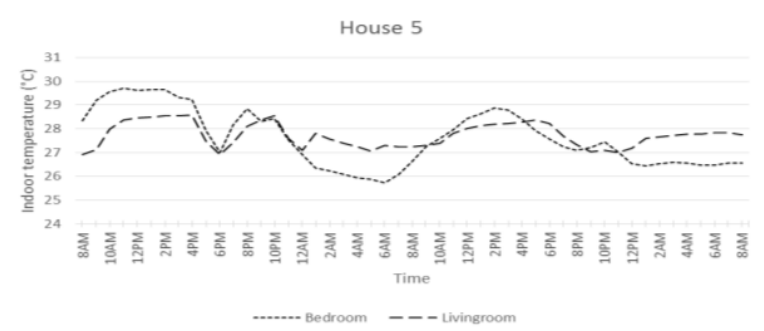

Fig. 10. The recorded indoor temperature of bedroom and living room of house 5 .

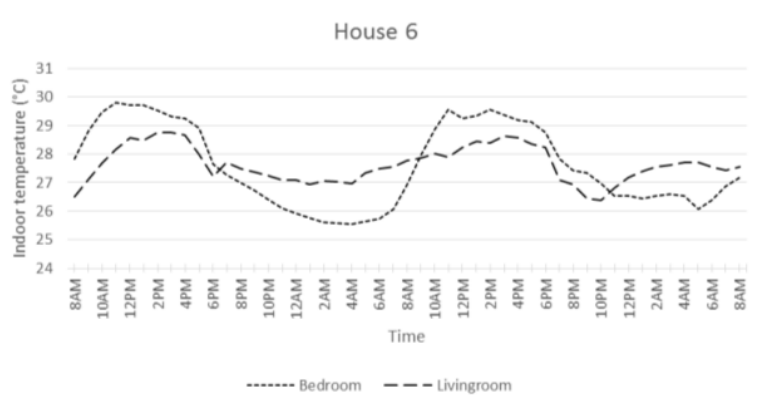

Fig. 11. The recorded indoor temperature of bedroom and living room of house 6.

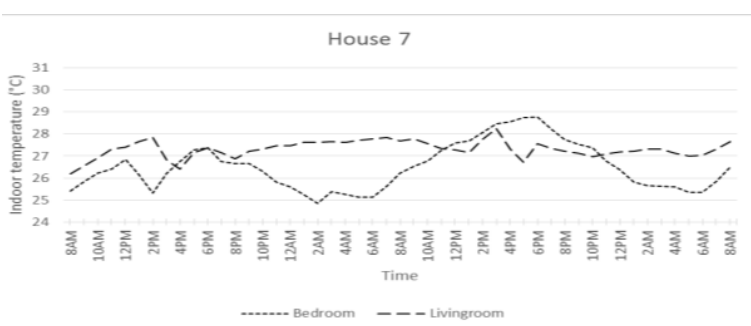

Fig. 12. The recorded indoor temperature of bedroom and living room of house 7 .

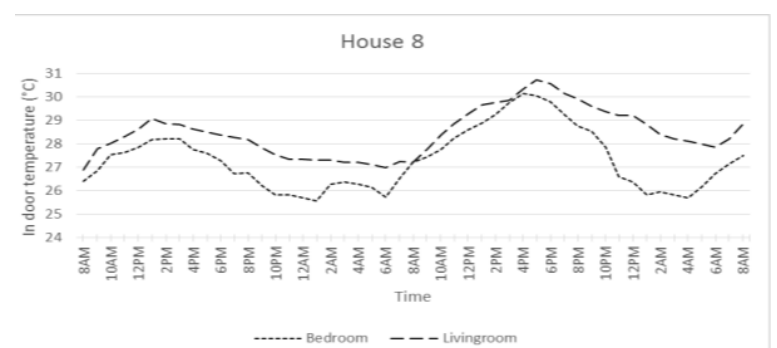

Fig. 13. The recorded indoor temperature of bedroom and living room of house 8 . 
Here, we observe that at night time, the bedroom temperatures were generally lower than the daytime (Figures 6 to 13). It was due to air conditioner usage during sleeping hours commonly from $10 \mathrm{pm}$ till 7 am. Besides the routine usage during night time, the $\mathrm{AC}$ also uses during the daytime, but it only when necessary. However, by the figures, we see that generally, the bedroom temperatures of the 8 houses own a similar pattern. However, since the objective of the study was to record the natural indoor temperature, the temperatures when the air conditioner on were omitted for averaging. The waiver period of indoor temperature without air conditioner was counted during the night sleeping period and for the non-routine activities. The non-routine activities were plotted by linking to respondents' questionnaire response of air conditioners on-off period of Figure 15 , which shows that in a majority, the occupants turn the air conditioners on at $11 \mathrm{am}$ to $3 \mathrm{pm}$. But when we link to Figures 6 to 13, we see that during the measurement period, the bedroom's air conditioner was mostly off for non-routine activities. Here, we decide to waive only the bedroom temperature during the night sleeping period.

On the other side, the indoor temperatures of some living rooms had a similar pattern of the bedroom temperatures, but the others (i.e., house 2 and 7) were more fluctuated. It was due to the usage of living rooms which did not have an exact pattern as was the bedroom. Similar to the temperature averaging of the bedroom, the living room temperatures also needed to be averaged without the air conditioner on. Diurnal temperature fluctuations during the measurement in the living room also did not have an exact pattern, especially for house 2 and 7 . Similar to the bedroom temperature averaging, the period when the air conditioners in the living rooms were on was omitted. The average of natural indoor temperature and the investigation of the relevancy of Luo Pan on bedrooms' and living room temperature is plotted in Table 1 and 2. Here we see that the average temperature recorded in both rooms shows either relevant or irrelevant to the good or bad terminology of Luo Pan Compass. Unfortunately, the relationship we have found here is in a negative meaning where bedrooms with a bad location due to Luo Pan experienced temperatures above the standard (SNI, 1993). Meanwhile, the living room temperatures are mostly reasonably relevant to the position due to Luo Pan. Table 1 shows that most houses did not practically apply the Luo Pan.

Based on the questionnaire survey, we learn that the observed houses are mostly of recent occupancy (under five years). It may mean that the studied houses are mostly occupied by a family of the young generation (Figure 14). There are 20\% of the

Table 1. Data of bedrooms' location, in-situ measurement and Luo Pan compass analysis

\begin{tabular}{cccccc}
\hline Objects & $\begin{array}{c}\text { House } \\
\text { orientation }\end{array}$ & $\begin{array}{c}\text { Bedrooms } \\
\text { location according } \\
\text { to Luo Pan (Figure 5) }\end{array}$ & $\begin{array}{c}\text { Indoor } \\
\text { temperature } \\
\text { of bedroom }\end{array}$ & $\begin{array}{c}\text { Maximum indoor } \\
\text { temperature } \\
\text { (SNI, 1993) }\end{array}$ & $\begin{array}{c}\text { Relevancy between recorded } \\
\text { temperature and location of } \\
\text { bedroom to Luo Pan Compass }\end{array}$ \\
\hline House 1 & West & $\mathrm{Bad}$ & $27.18^{\circ} \mathrm{C}$ & $27.1^{\circ} \mathrm{C}$ & Relevant \\
House 2 & West & $\mathrm{Bad}$ & $27.33^{\circ} \mathrm{C}$ & $27.1^{\circ} \mathrm{C}$ & Relevant \\
House 3 & North & $\mathrm{Bad}$ & $27.63^{\circ} \mathrm{C}$ & $27.1^{\circ} \mathrm{C}$ & Relevant \\
House 4 & South & $\mathrm{Bad}$ & $26.99^{\circ} \mathrm{C}$ & $27.1^{\circ} \mathrm{C}$ & Fairly relevant \\
House 5 & East & $\mathrm{Bad}$ & $27.72^{\circ} \mathrm{C}$ & $27.1^{\circ} \mathrm{C}$ & Relevant \\
House 6 & East & $\mathrm{Bad}$ & $27.93^{\circ} \mathrm{C}$ & $27.1^{\circ} \mathrm{C}$ & Relevant \\
House 7 & North & $\mathrm{Bad}$ & $27.10^{\circ} \mathrm{C}$ & $27.1^{\circ} \mathrm{C}$ & Relevant \\
House 8 & South & $\mathrm{Bad}$ & $27.62^{\circ} \mathrm{C}$ & $27.1^{\circ} \mathrm{C}$ & Relevant \\
\hline
\end{tabular}

Table 2. The data of living rooms, in-situ measurement and Luo Pan compass analysis

\begin{tabular}{lclccc}
\hline Objects & $\begin{array}{c}\text { House } \\
\text { orientation }\end{array}$ & $\begin{array}{c}\text { Living rooms } \\
\text { location according } \\
\text { to Luo Pan (Figure 5) }\end{array}$ & $\begin{array}{c}\text { Indoor } \\
\text { temperature } \\
\text { of livingroom }\end{array}$ & $\begin{array}{c}\text { Maximum indoor } \\
\text { temperature } \\
\text { (SNI, 1993) }\end{array}$ & $\begin{array}{c}\text { Relevancy between recorded } \\
\text { temperature and location of living } \\
\text { room to Luo Pan Compass }\end{array}$ \\
\hline House 1 & West & Bad & $26.86^{\circ} \mathrm{C}$ & $27.1^{\circ} \mathrm{C}$ & Fairly relevant \\
House 2 & West & Bad & $27.14^{\circ} \mathrm{C}$ & $27.1^{\circ} \mathrm{C}$ & Relevant \\
House 3 & North & In between good and bad & $26.95^{\circ} \mathrm{C}$ & $27.1^{\circ} \mathrm{C}$ & Fairly relevant \\
House 4 & South & In between good and bad & $26.91^{\circ} \mathrm{C}$ & $27.1^{\circ} \mathrm{C}$ & Fairly relevant \\
House 5 & East & Good & $27.73^{\circ} \mathrm{C}$ & $27.1^{\circ} \mathrm{C}$ & Irrelevant \\
House 6 & East & In between good and bad & $27.64^{\circ} \mathrm{C}$ & $27.1^{\circ} \mathrm{C}$ & Fairly relevant \\
House 7 & North & In between good and bad & $27.31^{\circ} \mathrm{C}$ & $27.1^{\circ} \mathrm{C}$ & Fairly relevant \\
House 8 & South & In between good and bad & $28.46^{\circ} \mathrm{C}$ & $27.1^{\circ} \mathrm{C}$ & Fairly relevant \\
\hline
\end{tabular}


observed houses admitted applying Pa Kua and Luo Pan. However, according to Table 1 and 2, most rooms were not in a proper "good" location, according to Luo Pan. There is an inconsistency between their acknowledgment of the Luo Pan application and the actual room location. There may be a link between the facts that they have applied the philosophy by themselves without any help from the designer or Feng Shui expert (Figure 14).

Figure 15 shows that the daytime usage of the bedrooms was quite significant with $\mathrm{AC}$ has been always on during usage that was why this period was also omitted for the indoor temperature averaging. The reason for using $\mathrm{AC}$ in the bedroom was also mostly initiated by the warm air. This condition was similar to that of the living room, but the AC was only partially on here. Meanwhile, the most reason for the AC usage was also by the warm air (Figure 16).

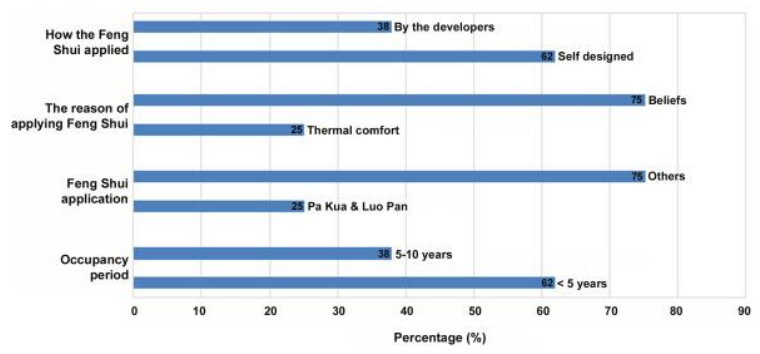

Fig. 14. Questionnaire survey response of housing occupancy and the Feng Shui beliefs.

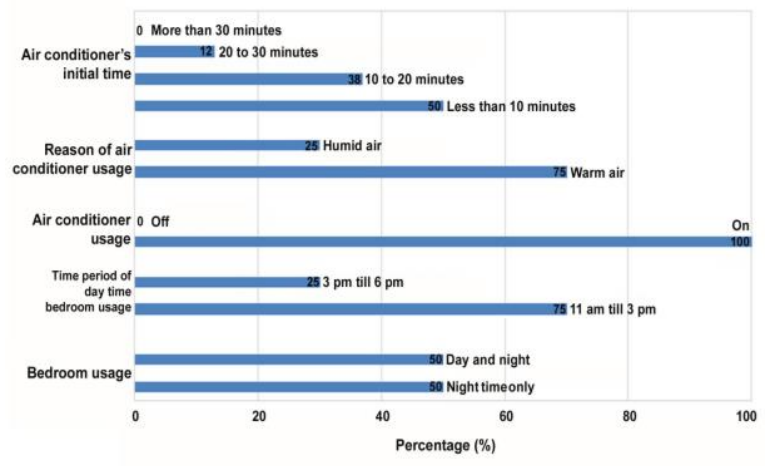

Fig. 15. Questionnaire survey response of bedroom condition.

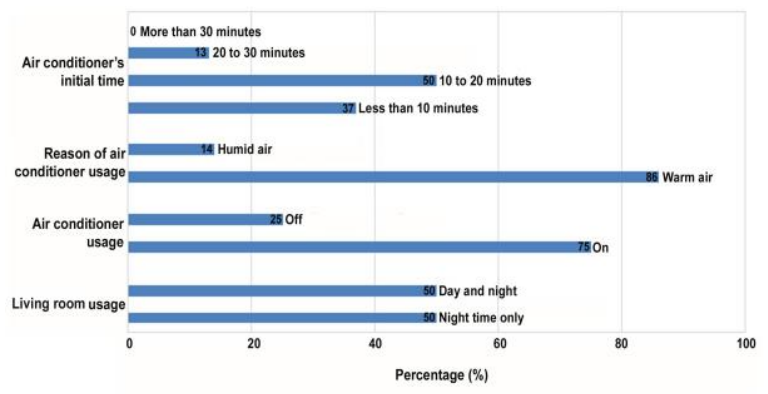

Fig. 16. Questionnaire survey response of living room condition.
The respondent survey has indicated that the initial time for the $\mathrm{AC}$ to lower the indoor temperature was more than 10 minutes, especially in the living room. The initial time of more than 10 minutes is considered unacceptable by occupants (Mediastika \& Hariyono, 2017). It corresponds to the data in Table 1, where the default temperatures before $\mathrm{AC}$ were mostly not within the standard. It also corresponds to the finding of Karyono (2000) and (2008) that temperature above the standard or even close to the standard was still regarded as uncomfortable.

\section{CONCLUSION}

The study shows that fair relevancy is developed between Luo Pan Compass and thermal comfort. A room located in a bad or in between a good and bad position has an uncomfortable indoor temperature. In general, it may show a good or bad location, according to Luo Pan Compass of the Feng Shui is somewhat relevant to indoor comfort or discomfort. Thus the unique compass is somewhat also pertinent to be adopted nowadays. Nonetheless, the study also indicates that even when the housing management allows the house owners to design their houses privately, the Chinese reside in the observed neighbourhood was no longer applied the Feng Shui wholly. Further quantitative studies to explore the reasons that caused it is recommended.

Indeed, the recorded indoor temperature could not be sorted by which temperature factors have a significant effect on the indoor temperature, whether it came from solar radiation or lack of natural airflow. Nonetheless, the recorded resultant ambient temperature truly represented the actual condition of the room daily. Therefore, the collected data is considered factual to study the relevance of indoor comfort and Feng Shui beliefs.

\section{ACKNOWLEDGMENT}

The study is a part of the final project of Bachelor in Architecture, Petra Christian University. The authors would like to send a deep gratitude to all participants involved.

\section{REFERENCES}

ASHRAE, A. (2010). Standard 55-2010: Thermal environmental conditions for human occupancy. 2010. American Society of heating, Refridgerating and Airconditioning Engineers: Atlanta.

Cheng, J., and Kong, S. (1993). Feng Shui and Architecture, Nanchang, Jiangxi Science and Technology Press (in Chinese). 
DeKay, M., and Brown, G. Z. (2013). Sun, wind, and light: architectural design strategies. John Wiley $\&$ Sons.

Dian, M. (1996A). Logika Feng Shui: Seni Mencapai Hidup Harmonis dan Bahagia Dalam Keberuntungan Bumi. Jakarta: PT Elex Media Komputindo.

Dian, M. (1996B). Logika Feng Shui: Konsep dan Metode Untuk Rumah Tinggal yang Membawa Keberuntungan Hidup. Jakarta: PT Elex Media Komputindo.

He, X., 1990, The Source of Feng Shui, Nanjing, Southeast University Press (in Chinese).

Karyono, T. H. (2000). Report on thermal comfort and building energy studies in Jakarta-Indonesia. Building and environment, 35(1), 7790.DOI: 10.1016/S0360-1323(98)00066-3

Karyono, T. H. (2008). Bandung thermal comfort study: assessing the applicability of an adaptive model in Indonesia. Architectural Science Review, 51(1), pp. 60-65. DOI: 10.3763/asre.2008. 5108

Kong, X. (1990). The Source of Feng Shui. Nanjing: South East University Press. 1990.

Mak, M.Y., and Ng, S.T. (2005). The art and science of Feng Shui-a study on architects' perception. Building and Environment, 40(3), pp. 427-434. DOI: 10.1016/ j.buildenv.2004.07.016.
Mak, M.Y., and Ng, S.T. (2008). Feng shui: an alternative framework for complexity in design. Architectural Engineering and Design Management, 4(1), pp. 58-72. DOI: 10.3763/aedm.2008.S307

Mediastika, C.E., and Hariyono, J. (2017). Wall Cladding Effects and Occupants' Perception of Indoor Temperature of Typical Student Apartments in Surabaya, Indonesia. Environmental and Climate Technologies, 20(1), pp. 51-66. DOI: 10.1515/rtuect-2017-0010.

Pheter, E., Solahuddin, M., and Mulyono, G. (2013). Penerapan Prinsip-prinsip Feng Shui Aliran Bentuk Pada Desain Interior Rumah Tinggal di Surabaya Timur (Studi Kasus Rumah Tinggal Bapak Joyo). Intra, 1(2).

Rossbach, S. (1983). Feng Shui, The Chinese Art of Placement. EP Dutton. Inc., NY.

Setiono, M. (2011). Asal Mula dan Pengaruh Keturunan Tionghoa di Jawa. Yogyakarta: Pelita Darma.

SNI T-14-1993-03. Prosedur umum konservasi "Tata Cara Perencanaan Teknis Konservasi Energi Pada Bangunan Gedung". Departemen Pekerjaan Umum, 1993.

Wicaksono, A. (2009). Tips Praktis Feng Shui Rumah Tinggal. Jakarta: Penebar Swadaya.

Yi, X. (2007). Membongkar Mitos Feng Shui. Jakarta: PT Bhuana Ilmu Populer. 